\title{
(Re)Imagining Law: Marginalised Bodies/Indigenous Spaces
}

\author{
Ben Hightower ${ }^{1} \cdot$ Kirsten Anker $^{2}$
}

Published online: 28 December 2015

(C) Springer Science+Business Media Dordrecht 2015

There are an infinite number of ways that the law marginalises groups of people. What is meant here by the word 'marginalise' is the sense that the law treats certain groups of people in particular ways: as inferior, less important, different to others, or as members of a periphery, and with the intention of forcing them into or maintaining their positions of powerlessness. In other words, if we consider the etymology of the word, these are moments that people are forced to the margo, or 'edge' of the law. Normally, the existence of legal obligations speaks to the way in which those within a society are bound to one another and to the law as an enforceable system of rules. This includes the myriad of national or international societies and their related laws. However, ironically, people remain bound to the law even if those legal systems exclude them; or put another way, they are included by their exclusion. The process of making such legal exclusions amounts to what Agamben might consider 'abandonment' by the law [1, pp. 28-29]. Rather than inclusion or complementary law, this practice reduces people to 'bare life' [1]; divorced from legal recognition and at the threshold of normalised political societies. This, according to Agamaben, has overwhelmingly become a 'technique of government' [2, p. 2]. ${ }^{1}$ Likewise, Foucault would see legal marginalisation as a

\footnotetext{
${ }^{1}$ Agamben notes that the state of exception, which he says is a "kind of exclusion" [1, p. 17], "tends increasingly to appear as the dominant paradigm of government in contemporary politics ... a technique of government" [2, p. 2].
}

Ben Hightower

bhightow@uow.edu.au

$\bowtie$ Kirsten Anker

Kirsten.anker@mcgill.ca

1 University of Wollongong, Wollongong, Australia

2 McGill University, Montreal, Canada 
form of biopower that has taken root in modern society as 'an explosion of numerous and diverse techniques for achieving the subjugations of bodies and the control of populations' [3, p. 140].

We can envisage that legal margins essentially operate like proverbial 'line in the sand'. Lines, be they physical or otherwise, form boundaries. They can divide or separate dimensional spaces. On the other hand, lines can also represent an association among things - a relationship, bond, distance, pathway or movement through space. In either instance, as a sign indicating a separation or an association, the line has potential to designate a 'here' and 'there', or, if we imagine the line closing upon itself, an 'inside' and an 'outside'. The passing over that separation enables-in Latin translatio (from which we get translation) and in Greek metapharein (from which we get metaphor) - at once, the construction of a proper and a foreign, as well as the possibility of hybrids, associations, and transgressions.

In the modern legal imagination, the separating line or margin indicates the space wherein something is allowed or accepted; or conversely, where something is no longer possible or acceptable - or at least that is what the law obliges us to accept. The line is the aesthetic representation par excellence of territorial borders and jurisdiction, of the limits of property and the idea of exclusion, of the citizen and the other, and of the very possibility of legal categories. This 'legal lineation' impacts upon different groups of people in a variety of ways. For instance, drawing lines on cartographic maps-both jurisdictional and proprietary-dispossesses Indigenous and local peoples from their lands, removing their rights and legal systems while subjugating them to colonial law and historiography. In another example, refugees are denied their internationally protected right to seek asylum at a country's border and reduced to Agamben's 'bare life' [1]. They are forced to a marginal existence without rights or legal subjectivity due to domestic laws and policies that link them with notions regarding security, citizenship, mandatory detention, national interest, and terrorism. As such, people lose their rights or recognition in the presence of the law. In other words, the law can be used to separate political beings from human bodies. Not only Indigenous people and refugees, but also GLBTIQ communities, women, children, the differently abled, the homeless, and so on, are all potentially marginalised simply due to the fact that they do not fit into everyday or accepted legal norms. In this way, entire groups of people are de-centred and depreciated by the force of this regulation which does not recognise or accept the personal realities that they live out on a day to day basis. Yet, it is when the law pushes people to the margins that sites of contest are opened up. As such, marginalised bodies attempt to challenge law makers and law enforcers, to cross and un-cross the boundaries of the legal imagination, and to create different possibilities; to (re)imagine the law. Semiotics allows us useful methods for exploring these interactions. For instance, signs (literal and metaphorical) utilised by interested groups, complementary and contrasting language employed in differing legal and social contexts, and acts of deterrence and defiance each give insights into the understanding of law's boundaries and traverses.

This Special Issue (SI) of the International Journal for the Semiotics of Law draws attention to a variety of contested sites that are opened up as a result of legal marginalisation. The SI is split into two parts, not by any type of line, margin, or 
distinction intended to separate or divide, but by one which demonstrates connectedness among the two parts to the overall theme. The first half of the SI stems from a call for papers that focuses on how different groups of people marginalised by legal regulation seek redress or to (re)imagine the law. Thus, for Ben Hightower, editor of 'Marginalised Bodies (Re)Imagining Law', semiotics is a useful way to explore the ways in which those pushed to or beyond the margins drawn by law challenge their abandonment or misrecognition in order to encourage amended legal systems that work best for them. This re-imagining includes a variety of challenges to legal language, perception, practice, culture and accountability. The second half of the SI includes submissions from a call for papers that situates marginalisation in the space of colonialism. For Kirsten Anker, editor of 'Signs in and Of Place: Indigenous Issues in Legal Semiotics', colonisation has been, and continues to be, both a contest of force and a struggle over semiotics. Signs of possession (such as cultivation or fences), representations of entitlement (savages and empty maps) and linguistic replacement and misappropriation (naming places, people and things, enforcing education in colonial languages) were, and continue to be, part of the arsenal of colonial law. In the modern era and the recognition of Indigenous rights, semiotics is central to the translation of Indigenous relationships to territories and into the language of property, as well as in the resignification of the place of law (and the law of Indigenous places) in the discourses of nationhood, resource development and environmental justice.

The five chapters that comprise 'Marginalised Bodies (Re)Imagining Law' each focus on very distinct groups of people and issues that have been identified by the contributing authors as being marginalised by the law: refugees, transgender people, sex workers, persons with intellectual and developmental disabilities, and students who come from marginalised groups in order to study law. This small but profound snapshot demonstrates the breadth of this field of inquiry.

Georgia Cole begins the theme by analysing the term 'refugee' and the ways in which that term can marginalise the very people that it was put in place to protect. Cole situates her argument within the context of Barthes' order of signification and the Saussaurean model of semiotics to address these concerns. Cole notes that while the term 'refugee' enjoys a long-established and 'legal-normative' history that is accepted internationally, it remains inherently fluid and therefore subject to varied interpretation and political instrumentalisation. She draws attention to the Cessation Clause for Rwandan refugees as a case study to illustrate how the word 'refugee' has been susceptible to numerous and simultaneous understandings which resulted in a sustained stalemate between Governments and the United Nations High Commissioner for Refugees. The result, according to Cole's analysis, is a series of bilateral concessions that appear to diminish the protracted refugee caseload, but actually fail to provide durable solutions or rectify the vulnerability of refugees in the region. Cole concludes that complementary sign interpretation of the term 'refugee' as well as an understanding of the motivations behind second-order signification should be reinforced in order to achieve positive and durable outcomes for vulnerable people seeking protection.

There is a multitude of ways that the law regulates and therefore, opens up sites of contest for GLBTIQ communities. In her article, Kimberly Wei Yi Tao discusses 
how transgender identity is situated within the legal context of the right to marry. Tao acknowledges that while many countries have a long history of recognising marriage as between a man and a woman, there are no 'statutory definitions' for gendered terms such as 'man', 'woman' 'male' or 'female'. As a result, the burden is placed upon judges to decide whether a transgender person is allowed to marry their partner. Tao is interested in the different principles and types of evidence; the 'sources of authority' that courts utilise in order to classify a person's gender for the purpose of marriage. Tao cites cases in the United Kingdom (Corbett $v$ Corbett 1971 and Bellinger $v$ Bellinger 2003), Hong Kong ( $W v$ Registrar of Marriages 2010, $2011 \& 2013$ ) and Australia (Secretary, Department of Social Security v State Rail Authority 1993 and Re Kevin 2002) to illustrate her points. Toa concludes by addressing how issues of gender, identity, marriage and the law currently play out in Hong Kong.

Stewart Cunningham discusses the perceived legal incompatibility between sex work (prostitution) and 'human dignity'. He notes that a number of international and domestic legal instruments operate under a framework that recognises this opposition. Cunningham's goal is not to provide a normative analysis of whether selling sex should or should not be considered 'dignified' behaviour. Instead, following the work of Laclau and Mouffe on discourse theory, Cunningham looks at how 'dignity talk' is utilised in discourse and the manner in which the non-static subject of sex workers can be challenged, resisted and remade. Cunningham finds that when courts enter into 'dignity talk' in cases of commercialised sex, stigmatised attitudes are reinforced that marginalise sex workers. The cases of $S v$ Jordan and others and Budhadev Karmaskar v State of West Bengal are highlighted in order to illustrate his points. Cunningham also analyses the response of sex workers; how they create their own 'dignity talk' and campaign for their rights and dignity as sex workers. Specifically, Cunningham points to the case in New Zealand of DML $v$ Montgomery and M\&T Enterprises Ltd as an example of how sex workers attempt to reform current sex work laws, which in turn, reforms cultural attitudes and stigmas. Cunningham concludes with an analysis of what he considers to be potential risks and benefits of 'dignity talk' in sex work discourse.

Katrina Powell, Jenny Dick-Mosher, Anisa Zvonkovic, and Pamela Teaster note that people with intellectual disabilities have been historically and discursively excluded by the State in theory and in practice. In the past, state-run facilities operated as sites where people with disabilities could be marginalised, kept separated from society, and blamed for their own 'immiseration'. As such, discourses surrounding disabled people have commonly been situated outside normative discourses of home, care, and quality of life. The authors seek to understand whether discourses surrounding state-run facilities and human rights have shifted in order to serve this marginalised and vulnerable group of people. Through an examination of the proposed closures of Virginia's Training Centres (state-run residential institutions for people with intellectual disabilities) the authors address the impacts of competing understandings of human rights concepts. On the one hand, some resident families have advocated for the facilities to remain open, citing human rights violations and concerns about quality of care. On the other hand, community of care advocates, also citing human rights, advocate for the closures of 
the Training Centres. Powell, Dick-Mosher, Zvonkovic, and Teaster observe rhetorics present in interviews, social media, and the law in order to show how human rights concepts are used by institutions, families, and lawmakers to rationalise decisions to either remove residents or keep them in state facilities. Theories on repudiation, abjection, and vulnerability are considered in order to lend some insights into the continuing debate.

The first four articles of 'Marginalised Bodies (Re)Imagining Law' deal with issues relating to vulnerable groups of people. Described in the simplest of terms, these articles show how law impacts upon people simply due to their identity as refugees, transgender people, sex workers, or intellectually disabled; how it keeps them regulated and, in effect, at the margins of legal consideration. In the final article, a slightly different approach to the theme is taken. Courtney Hanny considers a group of women who enter the legal practice 'from the margins' and subsequently make challenges to the dominant discourse community. Each of these women participated in a program funded by the Law School Admissions Council (LSAC) intended to increase enrolment of 'under-represented' groups. Hanny notes that these students were 'multiply marginalised' by gender as well as other factors, including refugee or immigrant status, religious affiliation, sexual identity, and/or an association with 'at risk' labelling. Hanny demonstrates how the entrance of these women as 'lawyers from the margins' informed their critique of the law and allowed them to contest the binary logic and normative criteria that create boundaries of exclusion and inclusion in these communities. These actions demonstrate a very personal demand for a more fluid interpretation of social justice work as well as a reworking of the relationship between justice (as an abstract ideal) and the law (as an institutionalized regime). For Hanny, these voices and perspectives from the margins have the ability to challenge the 'boundaries that define whose voices count within the legal system and to contest normative limits of semiotic potentialities for lawyers working toward more just social futures'.

For the contributors to the second part of this SI, 'Signs in and of place: Indigenous Issues in the semiotics of law', to speak of marginalisation by law begs the question of whose law. Certainly, they collectively tell a story of what Phillip Altmann describes in his contribution as 'law as a means of oppression'. However, the authors in this Special Issue also highlight that what was ignored, erased, mistranslated or denatured in the colonial legal strategy was in fact, Indigenous peoples' own law and forms of social ordering. The authors explore examples such as the historical doctrine of terra nullius that denied people the status of law (Kramer), the simplified forms of collective ownership in International law (Farget), as well as the inclusion, in Canadian jurisprudence, of Indigenous perspectives that are stripped of their normativity (Weir). Moreover, the legal orders and the selves that populate them are not hermetically sealed from one another. The semiotic field can be a fluid one, and Indigenous actors construct and re-construct legal meaning from across that field. Law's margins become law's pathways.

In the opening article, Philipp Altmann describes a classic pattern whereby laws affecting Indigenous peoples, produced by non-Indigenous actors, have historically either invisibilized inequalities by treating Indigenous people as universal citizens, or have targeted them for transformation into more convenient populations. 
However, in Ecuador, the site of Altmann's study, the state policy of 'indigenism' from the 1930s, in which Indigenous communities were incorporated into the rural structure of cooperative production, actually facilitated their consolidation as a political movement that both adopted and contested the existing legal framework. Altmann shows that the Indigenous movement in Ecuador has been 'constantly engaged in 'meaning work' - the struggle over the production of mobilizing and countermobilizing ideas.' In their semiotic struggles, Indigenous groups read various state structures in terms of an 'oppression frame' or a 'liberation frame'for instance, characterizing the existing state as bourgeois, white-mestizo, antidemocratic and submissive to international debtors, and their counterproposal as a plurinational or intercultural state, one that guarantees true democracy through decentralized local Indigenous territorial polities as well as dedicated offices within official state structures. Drawing on the language of human rights and selfdetermination, in particular from international instruments like the International Labour Organisation Convention 169, these strategies of both regional pluralism and integrated participation have been partially successful. In an argument reminiscent of E.P. Thompson's analysis of the ways in which peasants in eighteenth century England used law to argue for their customary rights in the face of the oppressive anti-poaching legislation-leading to his statement that 'the rule of law is an unqualified human good' [4]-Altmann observes that rights and laws are at once 'something created to oppress them ... and something that can be an instrument of self-liberation.' Laws and legal discourse can never be entirely captured by efforts to marginalize or silence.

Nevertheless, the subsequent three articles detail ways in which measures that purport to recognise Indigenous perspectives or modes of territoriality and social organization, and to rid state law of its colonial features, can surreptitiously reproduce those very features. In her French language contribution to this Special Issue, Doris Farget looks at how the very basic binary in liberal thought between individuals and the state is troubled by claims to collective Indigenous rights. In the Interamerican human rights system, territorial rights that seek to change the relationship between the state and Indigenous collectivities are justified by the Interamerican Commission via the way in which individual rights 'are realized in part or in whole through their guarantees to groups.' However, there are often a range of intermediate legal entities such as families or matrilineal clans with rights and obligations within traditional tenure systems, presented in evidence before the Interamerican Court, that are effectively effaced in the dichotomy between collective and individual rights that is used to 'think through' territorial occupation. The effect of this is further to mask the relations of power within Indigenous communities and nations-the marginalized within the marginalized-and to transform by simplification the internal rules around land use.

In Canada, the boundaries of territorial title have been extended physically to Indigenous occupation through the recognition of Aboriginal title but, in gestures towards 'the Aboriginal perspective' on proof and on the concept of rights themselves, the Supreme Court's jurisprudence has opened the way to the passage across legal boundaries, to hybridity and to inter-societal law. As Lorraine Weir's analysis of the treatment of oral tradition evidence in the recent Tsilhqot'in decision 
shows, the sites of contestation opened by Indigenous claims go to the deepest ontological and epistemological levels: namely, what things exist and how we can know them. However, argues Weir, the court's efforts to reconcile with the 'Aboriginal perspective' is a process by which it simply engages with its own constructions of 'the histories, languages and cultures of Indigenous nations' and fails to confront its own positivist perspective. Weir critiques this perspective and unpacks the common law's history of a 'hermeneutics of suspicion' towards oral sources via the archival science of Diplomatics and the concepts of tradition and memoria. The effects of this history are an attempt by the trial judge to parse Tsilhqot'in gwenIg as, at once, an oral history and a window into facts that happened, as well as an oral tradition that is a matter of belief largely irrelevant to enquiries supporting Aboriginal title. Epistemologically, it treats documents and witnesses alike as sources legibly re-presenting something original to the assessing eyes and ears of the judge, where the chain of observation or recording can be verified and authenticated. While oral tradition is thereby removed from the possibility of authentication-since its 'temporality [lies] in excess of the operations of genealogy' - its narratives are, at best, treated as having an 'underlying meaning' in the nature of myth and opened to a reading by the judge, rather than themselves constituting a form of knowledge, or, more strongly, constituting the law of the land.

In the troubling of categories produced by Indigenous claims, the colonial order must work to maintain its centrality and its legitimacy. Jillian Kramer traces the political fall-out in Australia after the initial recognition, in 1992, of native title specific to Indigenous groups with a connection to lands given by their traditional laws and customs. While the original discriminatory principle of terra nullius that justified the dispossession of Indigenous peoples was formally rejected in law, it becomes re-affirmed in legal and political discourse via allegedly race-neutral signifiers such as productivity, civility, legality, and the national interest. In particular, in the public speeches made by former Prime Minister John Howard, Indigenous claimants are positioned as 'special interest' groups threatening to undermine a race-less mainstream Australia that is striving for national unity. What is effectively effaced here are not the specificities of the Indigenous claimants as in the previous two articles, but the originary violence by which colonists abrogated to themselves the right to determine the national interest. What Aileen MoretonRobinson calls the 'possessive logic of patriarchal white sovereignty' [5] derives from the first illegal acts of possession and from the racial hierarchy that posited Indigenous peoples as un-civilized elements of the natural world and Europeans as civilized and thus, entitled to ownership. Yet this (now rejected) legal foundation is an iterable event that reproduces itself silently in every later decision.

The final paper approaches all these issues of margins and boundaries, insides and outsides, resistance and re-inscription, erasure and re-appropriation, subjection and agency, from a less orthodox location for legal commentary: contemporary art. The Indigenous artists explored by Oliver Watts are at once, like many of the marginalized subjects in the above texts, called forth or, as Watts puts it in borrowing from Althusser, 'interpellated' by conventional legal forms, yet also ape and rework them. His psychoanalytic reading shows that in the gap between law's official subject and the parts of the subject that are unassimilable, 'resistance is 
possible without relying on a modernist outsider position.' Watts argues that artists Gordon Bennett, Danie Mellor, Blak Douglas and Adam Geczy, in using the symbols of colonial sovereignty, national identity, and esoteric knowledge, avail themselves not of an 'activist mode asserting justice for the subaltern' but of the polysemy inherent to art, of the ability to probe the failures of a symbolic system with the force of over-proximity. In part, boundaries are confounded by these artists because they are themselves hybrid subjects (Bennett and Mellor have both Aboriginal and Anglo or Celtic backgrounds while Douglas and Geczy create a duo consisting of an Indigenous and a European artist). The point about national identity that Watts borrows from Žižek can be made about law's boundaries generally: 'an external border is reflected into an internal limit' [6, p. 110]. For example, since identifying English nationality distinguishes it from other nationalities, it also requires an internal investigation of who among the English represent 'real' Englishness paradigm. As Žižek notes: 'every empirical Englishman contains something "non-English", [6, p. 110]. Watts suggests that continuing this pursuit of internal limits finds 'a radical gap at the centre of law's authority' that is sustained not by reason or justification but by image, ritual and fantasy. At this place, there is always the possibility of re-imagining law.

\section{References}

1. Agamben, G. 1995. Homer Sacer: Il potere sovrano e la nuda vita. (trans: Daniel Heller-Roazen) Homo Sacer: Sovereign Power and Bare Life. Stanford: Stanford University Press. 1998.

2. Agamben, G. 2004. State of exception (trans: Kevin Attell). Chicago: Chicago University Press.

3. Foucault, M. 1998. The history of sexuality Vol. 1: The will to knowledge. London: Penguin.

4. Thompson, E.P. 1975. Whigs and hunters: The origin of the black act. New York: Pantheon Books.

5. Moreton-Robinson, A. 2004. The possessive logic of patriarchal white sovereignty: The High Court and the Yorta Yorta decision. Borderlands 3: 2.

6. Žižek, S. 2002. For they know not what they do: Enjoyment as a political factor, 2nd ed. London: Verso. 